\title{
Estetyka przeszłości w przekazach dla najmłodszych w świetle uwag o filogenezie kulturowej
}

\section{Aesthetics of the past in the transmission for the youngest, in the light of the cultural phylogenesis}

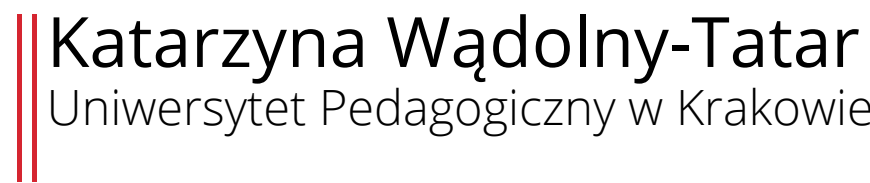

\begin{abstract}
A character of the history's transmission depends on the aesthetics of the past in literature for the youngest. Works, addressed to a young audience in different age, allow to maintain the rules of the cultural phylogenesis, understood as a need of acquiring the cultural and social competences by successive human generations during their whole life, in a specific order (inter alia - with priority of the natural ways of communication before the unnatural, a book before an e-book). Aesthetisation of the past contains: (1) synecdoche as a visual clue in the illustrations contained in the works concerning th Second World War (series: Wojny dorosłych - historie dzieci (War of Adults, Stories of Children); (2) biography strategies used in the literature for young readers by Anna Czerwińska-Rydel.
\end{abstract}

Key words: aesthetics of the past, cultural phylogenesis, synecdoche, biography strategies

Streszczenie: Od estetyki przeszłości w literaturze dla najmłodszych zależy charakter transmisji dziejów. Utwory, adresowane do małych odbiorców w różnym wieku, pozwalają na zachowanie zasad filogenezy kulturowej, rozumianej jako konieczne nabywanie kulturowych i społecznych kompetencji przez kolejne ludzkie pokolenia w ciągu całego życia w określonym porządku (między innymi z pierwszeństwem naturalnych środków komunikacji przed sztucznymi, prymatem książki drukowanej nad książką elektroniczną). W estetyzacji przeszłości uczestniczą: (1) synekdocha jako trop wizualny w ilustracjach zawartych w utworach dotyczących drugiej wojny światowej (seria Wojny dorosłych - historie dzieci); (2) strategie biografizacyjne stosowane w prozie dla młodych czytelników przez Annę Czerwińską-Rydel.

Słowa kluczowe: estetyka przeszłości, filogeneza kulturowa, synekdocha, strategie biograficzne

Warszawski badacz literatury dla dzieci i młodzieży w klauzuli jednego ze swoich artykułów stwierdza:

Uwewnętrznienie wartości, które są wpisane w naszą egzystencję, które są pierwotne i przeżyte, nie tylko przyswojone, ale przede wszystkim zinterioryzowane, 
jest warunkiem rozwoju człowieka, a to decyduje o humanistycznym wymiarze ludzkiej natury i o fundamentach więzi społecznych. Lektura książki jest pod tym względem doświadczeniem niemożliwym do przecenienia: jest wydarzeniem procesualnym, czasowym i aktywnym (Leszczyński 2015, 182).

Owa aksjologiczna interioryzacja staje się możliwa dzięki Gadamerowskiej fuzji horyzontów w lekturze czy efektowi inskrypcji, jak powiedziałby Jacques Derrida - by przywołać teoretycznoliterackie ustalenia, wywiedzione przecież z praktyki i w niej na powrót sprawdzalne - a wywołuje je zetknięcie literatury i pamięci. Doświadczenie czasu, najczęściej mentalne, pozwala wpisać pamięć jednostkową w zbiorową, rzutować pojedyncze przeżycia (mikrohistorię) na kolektywne tło (makrohistorię). Czytelniczy odbiór przekazu powoduje specyficzne odwrócenie biegu czasu jako doświadczenia wewnętrznego, próba zrozumienia przeszłości stanowi antecedencyjną siłę skierowaną wstecz, umożliwia również pokoleniową perspektywę postpamięci.

Filogenezę kulturową rozumiem jako konieczne nabywanie kulturowych i społecznych kompetencji przez kolejne ludzkie pokolenia $w$ ciągu całego życia w określonym porządku. Ów porządek jako kolejność zaplanowanych (ale z pewnością też i przypadkowych) działań (oddziaływań) formacyjnych ma w tak postrzeganym rozwoju pokoleń, społeczeństw zasadnicze znaczenie. Dobrze realizują go utrwalone pedagogiczne zasady, wyznaczające kierunek nabywania umiejętności, przyswajania wiedzy: od bliskiego do dalekiego, od znanego do nieznanego, realizowane $\mathrm{w}$ rytmie, który można nazwać powtórzeniem ze zmianą. W procesy filogenetyczne wpisane jest wspólne źródło i początek, jakiś względnie wyrównany start, podobieństwo - jak w wyglądzie ludzkich i zwierzęcych zarodków w ich wstępnych fazach rozwoju, zanim biologiczne drogi tych organizmów się rozejdą.

Filogeneza kulturowa zakłada zatem oczywiste pierwszeństwo naturalnych środków komunikacji przed sztucznymi, pierwotnych przed wtórnymi, cywilizacyjnie utrwalonych przed nowiniarskimi i eksperymentatorskimi. W rozwoju małego człowieka, jego osobniczej ontogenezie, oznacza to prymat mowy nad pismem czy też ustności nad piśmiennością, książki drukowanej nad książką elektroniczną, tradycyjnej ilustracji książkowej nad elektronicznym obrazem, obrazu (także obrazu litery i słowa, co ma później niebagatelne znaczenie z praktyce ortograficznego zapisu, nauki ortografii w ogóle) nad dekodowanym „symbolicznym porządkiem” (Jacques Lacan) pisma. Kulturowa filogeneza sugeruje stopniowy ruch dyrektywny z jednego „wspólnego” bieguna w kierunku drugiego, nie tracąc z pola widzenia pierwszego, a przynajmniej pamięci o nim. Przypomina to konieczne balansowanie między sferami tożsamości: idem - ipse (Paul Ricoeur) albo strukturami: instytucja - idiom (Jacques Derrida), gdy w obu sytuacjach pierwsze składniki opozycji nazywają to, co wspólne i znormalizowane, drugie - to, co niepowtarzalne, indywidualne, odmienne. Jeden biegun nie istnieje bez drugiego, 
żaden nie jest osiągalny, stanowi jedynie asymptotę, do której jednostka (albo jej wytwór) może się zbliżyć, będąc w nieustannym ruchu: fizycznym, mentalnym (twórczym, interpretacyjnym). Za autorem Wielkiej zabawy można też powiedzieć, że pojawienie się świata na opak musi poprzedzać rozpoznanie porządku, któremu ta zmiana zaprzecza (Cieślikowski 1985). Świadomość tej diachronii, procesów i etapów, powinien mieć dorosły jako pośrednik w lekturze świata, społeczno-kulturowy przewodnik, działający w kręgu rodziny, potem przedszkola i szkoły, dysponujący czasem i po prostu obecny (z otwartym umysłem, skupiony na wykonywanej czynności i kontakcie z dzieckiem). Dziecko postrzega świat synchronicznie, z perspektywy swojego „tu” i „teraz”, najpierw uczy się w sposób prosty odpowiadać na pytanie: „kim jestem”, zanim podejmie próbę odpowiedzi na filogenetycznie skrajne - antecedencyjne: „skąd przychodzę”, antycypacyjne: „dokąd zmierzam".

Współczesny księgarski rynek dla dzieci i młodzieży jest niezwykle bogaty i zróżnicowany, co niewątpliwie sprzyja odbywaniu właściwej drogi filogenetyczno-kulturowej - od książki drukowanej do elektronicznej, od książki czytanej głośno dziecku siedzącemu obok do samotnie słuchanej płyty z nagraniem cudzej interpretacji (audiobooka), rzutującej przecież na odbiór dzieła. Głosowa interpretacja na nośniku może ulec jedynie mechanicznemu zatrzymaniu czy powtórzeniu, nie odpowie na pytania dziecka, nie dostrzeże jego reakcji.

$\mathrm{Na}$ wczesnych etapach odbioru dzieła literackiego ilustracja towarzysząca tekstowi ma niebagatelne znaczenie $\mathrm{w}$ zrozumieniu przekazu, dla słuchającego reprezentuje czytaną treść, i może to czynić w sposób dosłowny czy realistyczno-mimetyczny i / lub metaforyczny, z użyciem tropów jako chwytów wizualnych. Dobra ilustracja nie powinna stanowić obojętnego sąsiedztwa tekstu (Kłakówna 1998), wchodzi z nim w korelacje, wytwarza analogiczny świat, a niekiedy zastępuje ten, który jawi się w lekturze tekstu pisanego, nawet go przekracza. Jest wiarygodna, nie zawiera błędów i uchybień, wynikających z niedoczytania tekstu przez ilustratora, charakteryzuje się starannością wykonania, ma wysokie walory artystyczne. Jest jak pokarm dla duszy wchłaniany przez dziecko oczyma. Dobra ilustracja, podobnie jak przekaz słowny, wymaga interpretacji, odniesienia do słowa i do niej samej, prowokuje zatem przerwy w czytaniu tekstu - na rozmowę dziecka $\mathrm{z}$ dorosłym, dorosłego z dzieckiem. Wyzwala emocje - każde dziecko spotyka w lekturze obrazy, które budzą w nim niepokój i lęk (niektórych nie chce powtórnie oglądać), jak i te, które niosą pozytywne doznania.

Jeśli filogenetyczne czytanie obrazu ma pierwszeństwo przed czytaniem słowa, to przekaz wizualny nie powinien być lekceważony, ani traktowany jako mało znaczący ozdobnik i dodatek do literalnego zapisu. Gdy dorosły czyta, siedzący obok słuchacz jest jednocześnie widzem wpatrującym się w obraz. A zatem czytanie obrazu i dobre przygotowanie rodziców (ich chęć), 
nauczycieli do tego zadania wydaje się priorytetowe, podobnie jak umiejętność wyboru przez nich wartościowego tekstu z ilustracjami do pracy z dzieckiem.

Wielki potencjał tkwi w tropologii przekazu wizualnego. Metaforę, ironię czy synekdochę „można zobaczyć” (Porębski 1980). Ten ostatni trop, tworzący układy: pars pro toto i totum pro parte, stanowi substytucyjny, oparty na szczegółowym lub ogólnym obrazowaniu i proporcjach sposób komunikowania o sytuacji, w której właśnie część reprezentuje całość, jak również całość, na zasadzie uogólnienia, odnosi się do części. Synekdocha sprzyja eufemizacji trudnych i problematycznych treści. Jej zastosowanie może na przykład łagodzić dramatyzm historii w książkach dla młodych odbiorców.

W niezwykle przemyślany sposób zastosowano ten trop w ilustracjach zamieszczonych w utworach dotyczących II wojny światowej i okupacji Polski, wydanych w ramach serii Wojny dorosłych - historie dzieci przez łódzkie wydawnictwo Literatura, przy współudziale Muzeum Powstania Warszawskiego. Opowieści autorstwa Pawła Beręsewicza, Renaty Piątkowskiej, Doroty Combrzyńskiej-Nogali czy Joanny Papuzińskiej otrzymały znakomite uzupełnienie graficzne w postaci ilustracji Macieja Szymanowicza, Joanny Rusinek. Opowiedziane „na nowo” i opowiedziane „dalej” (Burzyńska 2006) historie mają walor prywatności, indywidualnego doświadczenia, pochodzącego z cudzych przekazów (bohaterów-informatorów, którzy przeżyli tragedię wojny) albo - jak w Asiuni i Moim tacie szczęściarzu Papuzińskiej - stanowią relacje z autopsji. Zarówno twórcy słowa, jak i obrazu nie epatują okrucieństwem, zwłaszcza ilustratorzy dokonują kondensacji treści, jedynie sugerując określony rozwój zdarzeń. Wielu z nich wybiera „zastępstwo” synekdochy, która dodatkowo wyprowadza niebezpieczeństwo „poza kartkę". Dzieje się tak, gdy ilustrator przedstawia los małej Chany, siostry głównego bohatera prozy Piątkowskiej Wszystkie moje mamy (Piątkowska 2014), poprzez małą historię chłopca, opowiadającą o działalności Ireny Sendlerowej, na dwóch sąsiadujących ze sobą stronach. Na jednej z nich wystający spod kołdry warkoczyk dziewczynki informuje o miejscu jej ukrycia i jest substytucją samej bohaterki (częścią zamiast całości), na drugiej widać już obozową latarnię jako charakterystyczny element wyposażenia miejsca kaźni. Łóżko, w którym próbowała się ukryć Chana, i latarnię łączy „szlaczek” z kolczastych drutów - spajając obie ilustracje i narrację, wskazując na finał życia dziewczynki.

Zastosowanie synekdochy jest charakterystyczne również dla obrazowych ujęć Joanny Rusinek. Czerwony płaszczyk bohatera Zaklęcia $n a, w^{\prime}$ Michała Rusinka (Rusinek 2011) nieodmiennie budzi skojarzenia z prozą Romy Ligockiej i filmem Stevena Spielberga Lista Schindlera. Jednak poza tą interkulturowością czytelną dla dorosłego, odwzorowuje narracyjne realia wojny, jest bowiem - jako ubranie przeszyte z płaszcza ojca - jedyną po nim pamiątką $\mathrm{w}$ „widocznym” kolorze na tle niewidocznych, 
niewidzialnych barw. Stanowi efekt „radzenia sobie”, wojennej habituacji, dotyczącej uzyskiwania pożywienia, lekarstw, ubrań.

Przykładem autorskiej książki w zakresie słowa i obrazu, w której oba kody informacyjne mają wyrównany udział, jest Pamiętnik Blumki Iwony Chmielewskiej (Chmielewska 2011) traktujący o przedwojennym warszawskim domu sierot i Januszu Korczaku. Ilustracje nawiązują do gatunku wypowiedzi swoją fakturowością, kartki z zeszytu, na którym mogły być prowadzone zapiski dziewczynki, zostają „użyte” do budowy różnych elementów obrazu. Odpowiednio złożona i przycięta przestrzeń kartki staje się między innymi siatką ulic stolicy, ogrodową ławką, płotem z otwartą furtką, kaloryferem, na którym suszą się dziecięce ubrania po zimowej zabawie, stopniami schodów i na koniec konstrukcją wagonu kolejowego, w którym podopieczni Korczaka i on sam odbyli swoją ostatnią podróż. Każdy z tych elementów stanowi wycinek jakiejś przestrzeni - „papierowej” i rzeczywistej, synekdochicznie ją zastępując i metaforyzując. Wspomniana finalna scena ilustracyjnie przedstawia połowę wagonu, którego dalsza część istnieje „poza kartką”. Pióro „po” Blumce, którym już niczego nie napisze, zakończone małą dłonią zamiast stalówki, podwójnie wskazuje na ów wagon - w deiktycznym rysunkowym geście oraz przenośnie, interpretacyjnie.

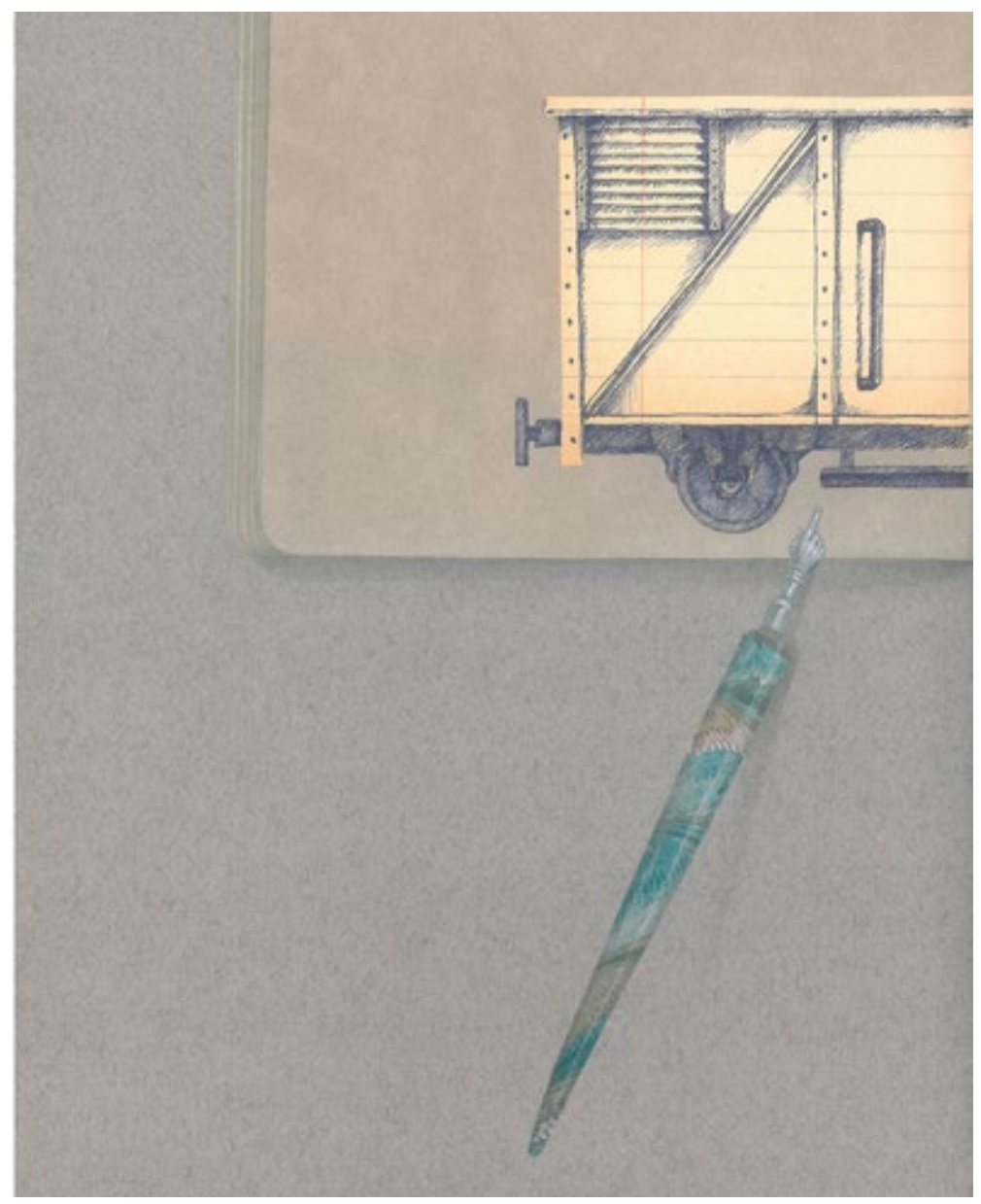

Ilustracja zamykająca ciąg słowno-obrazowy w utworze Iwony Chmielewskiej, 2011, Pamiętnik Blumki, Poznań.

Polonistyka. Innowacje 
Synekdocha jest podstawowym środkiem wyrazu w innym utworze o Korczaku - Jest taka historia. Opowieść o Januszu Korczaku Beaty Ostrowickiej (Ostrowicka 2012), z ilustracjami Joli Richter-Magnuszewskiej. Mediatorem między współczesnością a przeszłością staje się w tej narracji prababcia małego chłopca, dawna wychowanka domu sierot. Zdarzenia relacjonowane przez nią prawnukowi, uprzednio wielokrotnie - teraz w opowieści „zapisanej”, są opowiadane jakby pierwszy raz dla czytelnika, chłopiec zdradza bowiem potrzebę uniknięcia pewnych szczegółów opowieści, wie też, w jakich sytuacjach prababcia prawdopodobnie zawiesi głos lub przerwie opowieść. Historia wojenna toczy się więc w ramach prywatnej historii rodziny, co - podobnie jak zastosowanie synekdochy do modelowania opowieści - wydaje się zgodne z założeniami nowoczesnego historyzmu, według którego tylko mała historia (mikrohistoria) udostępnia tę wielką (makrohistorię), a indywidualne doświadczenie historii decyduje o pojmowaniu dziejów. Richter-Magnuszewska prowadzi swoją obrazową opowieść równolegle, ale jakby na krawędziach kartki czy na obrzeżach mimetyzmu i realizmu ilustracyjnego. W ten sposób nie oszukuje młodego odbiorcy i nie pozbawia go wiedzy o zdarzeniach, podaje ją jednak w sposób złagodzony, nieostry. Tekst zawsze jest publikowany na tle będącym częścią obrazu, co spaja i splata dwa toki przekazu. Jedna z ilustracji, wykorzystująca brzegi książki jako przestrzeni graficznej, pokazuje niebezpieczeństwo wypędzenia, wysiedlenia małych mieszkańców placówki Korczaka.

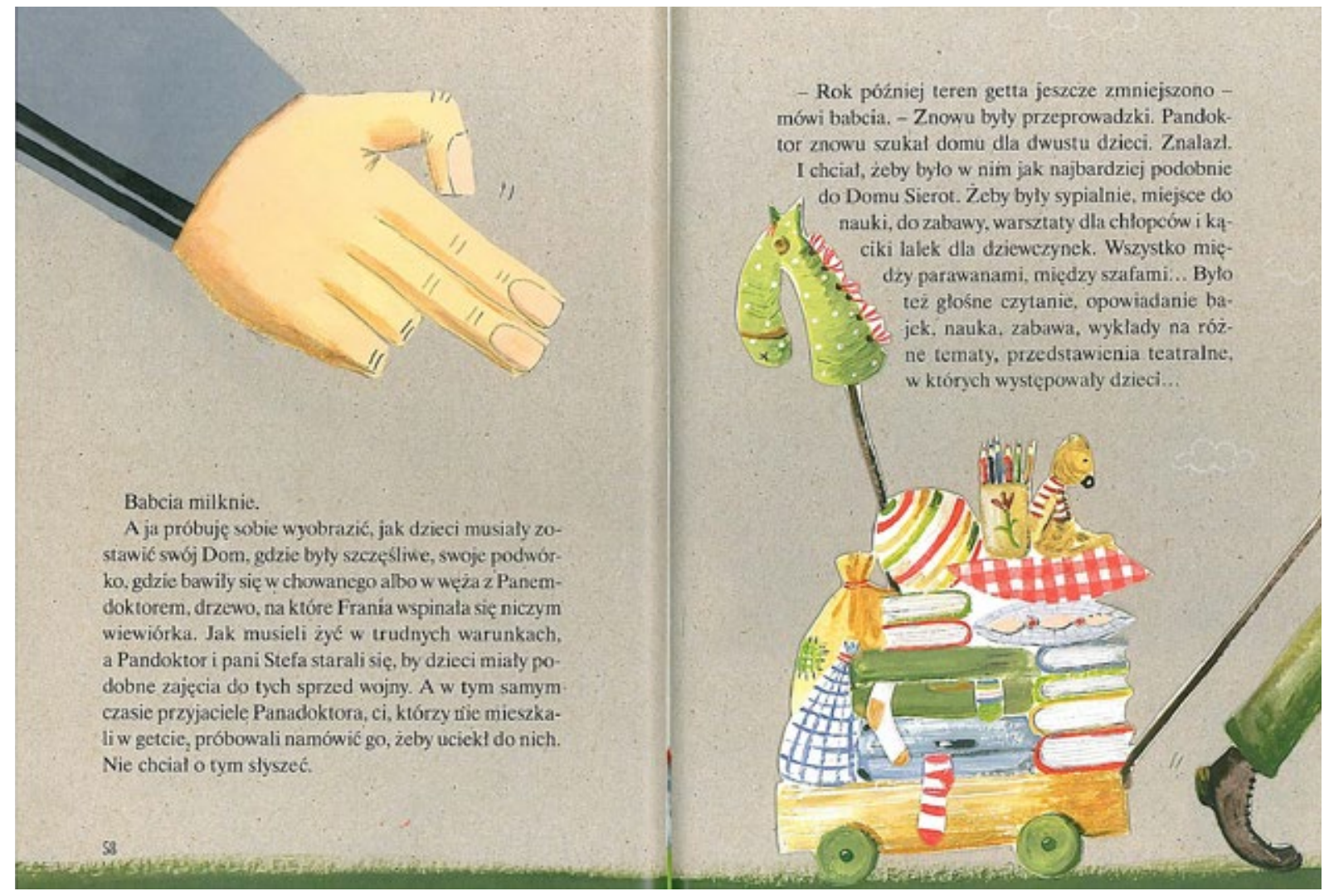

Ilustracja z książki Beaty Ostrowickiej, 2012, Jest taka historia. Opowieść o Januszu Korczaku, Richter-Magnuszewska J. (il.), Łódź. 
$\mathrm{Z}$ jednaj strony jako pars pro toto funkcjonuje tutaj ręka nazisty w geście nakazu opuszczenia terytorium, z jednoczesnym układem palców jak do strzału z broni palnej, co można interpretować na granicy dramatu i zabawy w strzelaninę, wojnę. Z drugiej pojawia się realizująca nakazany kierunek wyjścia, idąca „poza kartkę” chłopięca postać, której jedna noga i ciągnięty wózek z zabawkami i osobistymi rzeczami mieszczą się w granicach przestrzeni stronicy. To także specyficzne ilustracyjne kawałkowanie ciał postaci i zabieg fokalizacyjny. Ilustracja zamykająca książkę ma charakter terminalnego ogarnienia totum pro parte tego, co tajemnicze, numinotyczne i egzystencjalnie graniczne.

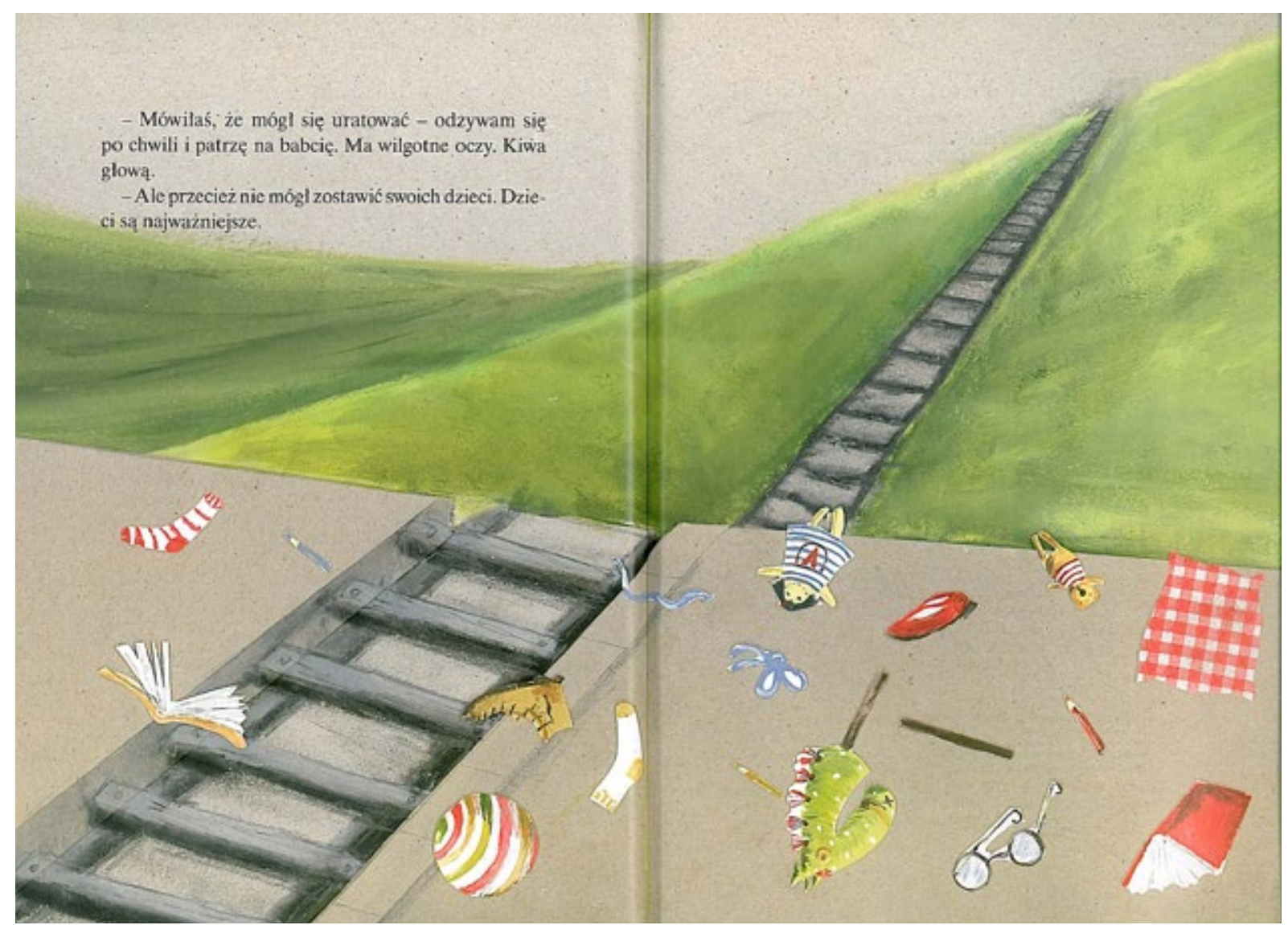

Ilustracja zamykająca narrację Beaty Ostrowickiej, 2012, Jest taka historia. Opowieść o Januszu Korczaku, Richter-Magnuszewska J. (il.), Łódź.

Granice światów podkreśla przesunięcie obrazów względem siebie, ich kolorystyka, dowartościowująca tę nieznaną przestrzeń niczym Elizjum, Raj. Kolejowe tory wiodą gdzieś poza horyzont. Natomiast mały odbiorca z łatwością rozpozna wśród rozrzuconych wokół nich przedmiotów te, które uprzednio wiózł na wózku mały chłopiec, a jeszcze wcześniej należały do konkretnych postaci fabularnych. W ten sposób wytwarza się spójny przekaz graficzny dążący do kompletności narracyjnej, dobrze przecież zespolonej ze słowem, przedstawiającej tutaj przebieg życia w perspektywie odbioru modelowanego przez śmierć. Nienachalny, niedosłowny i dbający o emocjonalne bezpieczeństwo najmłodszych odbiorców sposób transmisji 
dramatu dziejów, traumy wojennej daje szansę rozmowy poprzez książkę i jej lekturę, lecz także „obok” nich.

Wizualne rozwiązania wprowadzone w powyższych utworach przekonują też o cykliczności ilustracji jako zabiegu wytwarzającym opowieść korespondującą z komunikatem słownym, ale także go przekraczającym, ponieważ obraz może być nośnikiem pozatekstowych (w danej korelacji) metaforycznych czy symbolicznych informacji.

Wobec wielości publikacji, dotyczących kulturowo-naukowych patronów danego roku (rokiem Janusza Korczaka był 2012), można mówić o pewnej okazjonalności takiej formy propagowania treści narodowo-historycznych, dydaktyczno-poznawczych. Zjawisko to samo w sobie, choć związane w ekonomią rynku wydawniczego i jego komercjalizacją, nie musi podlegać negatywnej ocenie, zwłaszcza jeśli efektem tego stymulowanego twórczego ożywienia bywają dobre książki.

Rocznicowy charakter mają również literackie biografie ludzi nauki i sztuki tworzone przez Annę Czerwińską-Rydel. Gdańska pisarka specjalizuje się w osobowych (re)konstrukcjach wielkich Polaków - muzyków (Fryderyk Chopin, Henryk Wieniawski, Witold Lutosławski), literatów (Aleksander Fredro, Kornel Makuszyński, Julian Tuwim), naukowców (Maria Skłodowska-Curie, Jan Czochralski), filozofów, pedagogów. Faktografia miesza się $\mathrm{w}$ powieściach Czerwińskiej-Rydel z fikcjonalnością zdarzeń, w wytwarzaniu „magii wiarygodności” (Michałowska 2011) pomagają fotografie opisywanych osób, graficznie adaptowane na potrzeby narracji dla najmłodszych. Każda z powieści realizuje inną strategię narracyjną, przekładającą się również na kompozycję dzieła. Sto tysięcy kartek. Opowieść o Józefie Ignacym Kraszewskim (Czerwińska-Rydel 2014) zostaje poprowadzona na styku dwóch horyzontów czasowych. Powieściowe „tu i teraz” stanowi rodzinna sytuacja nastoletniego Kuby i konieczność spędzenia w okolicy Puszczy Białowieskiej wakacji u stryja, który jako naukowy pracownik uniwersytecki pisze książkę o Józefie Ignacym Kraszewskim. Z nauką męskich zajęć, inicjowanych przez stryja, idzie w parze umowa o codziennej lekturze chłopca, z założenia odzwyczajająca go od gier komputerowych. Męskie pisanie „po kawałku” i chłopięce czytanie „po kawałku” okazuje się intrygujące dla młodego bohatera, oczekującego na kolejne "odcinki” powieści. „Odcinkowana” jest zresztą powieść Czerwińskiej-Rydel, dzielona na niemal naprzemienne rozdziały o wakacyjnej aktualności chłopca $\mathrm{i}$ „kartki” z powieści stryja. Symultanizm jest tutaj efektem lektury, bo wspomniane różnice horyzontów czasowych (czasy Kraszewskiego i XXI wiek nastolatka) nie pozwalają mu zaistnieć jako literackiej technice temporalnej. Z kolei w narracji biograficznej o Julianie Tuwimie (Czerwińska-Rydel 2013b) ekspozycji podlega, jako narratorka, jego młodsza siostra, późniejsza znana tłumaczka Kubusia Puchatka i Chatki Puchatka, mała Irenka Tuwim. Zaś w Fotelu czasu (Czerwińska-Rydel 2013a) tytułowy przedmiot umożliwia podróże w czasie kilkuletniemu potomkowi rodziny Fredrów 
do czasów pradziada. Bohater obserwuje funkcjonowanie dawnej rodziny, wielodzietnej i wielopokoleniowej, prowadzenie domowego gospodarstwo, towarzyskie konwenanse, edukację młodego pokolenia, kulturę kulinarną. Walory poznawczo-historyczne mają zresztą wszystkie biograficzne powieści pisarki, w których przedstawia dzieciństwo swoich bohaterów i portretuje ich w konstelacji rodziny.

Sentymentalne estetyzacje przeszłości widoczne są w książkach niektórych pisarzy, przybliżających młodym odbiorcom własne dzieciństwo (Kasdepke, Onichimowska 2009; Rusinek, Olech 2010; Górnicka-Boratyńska 2011), a także w wydawniczych inicjatywach, jak publikacja reprintów dawnych książek dla dzieci przez Muzeum Książki Dziecięcej. Wydaje się, że w najnowszej literaturze dla dzieci kulturowa teoria literatury, obfitująca w najrozmaitsze zwroty (topograficzny, biograficzny, somatyczny i sensualny, etyczny i inne), znajduje swoje dobre odbicie i potwierdzenie. Jest w niej miejsce również na estetykę przeszłości, międzypokoleniową transmisję historii, czynioną wielopoziomowo ze względu na wiekowe zróżnicowanie odbiorców, z udziałem słowa i obrazu, i przy zachowaniu dyrektyw filogenezy kulturowej.

\section{Bibliografia:}

Burzyńska Anna, 2006, Kariera narracji. O zwrocie narratywistycznym w humanistyce, w: Anty-teoria literatury, Kraków, s. 119-148.

Chmielewska Iwona, 2011, Pamiętnik Blumki, Poznań.

Cieślikowski Jerzy, 1985, Świat na opak, w: Wielka zabawa. Folklor dziecięcy. Wyobraźnia dziecka. Wiersze dla dzieci, Wrocław, s. 235-238.

Czerwińska-Rydel Anna, 2013a, Fotel czasu, Łoskot-Cichocka D. (il.), Warszawa. Czerwińska-Rydel Anna, 2013b, Mój brat czarodziej, Nowacka D. (oprac. graf.), Łódź.

Czerwińska-Rydel Anna, 2014, Sto tysięcy kartek. Opowieść o Józefie Ignacym Kraszewskim, Bajtlik J. (il.), Warszawa.

Górnicka-Boratyńska Aneta, 2011, Zielone pomarańcze, czyli PRL dla dzieci, Butenko B. (oprac. graf.), Warszawa.

Kasdepke Grzegorz, Onichimowska Anna, 2009, Kiedy byłem mały / Kiedy byłam mała, Olech J. (il.), Łódź.

Kłakówna Zofia Agnieszka, 1998, Projektowanie sytuacji odbioru tekstów kultury, w: Kwiatkowska-Ratajczak M., Wysłouch S. (red.), Konteksty polonistycznej edukacji, Poznań, s. 108-121.

Leszczyński Grzegorz, 2015, „Kto ty jesteś?” Literatura XXI w. w poszukiwaniu tożsamości młodego pokolenia, w: Ungeheuer-Gołąb A., Chrobak M., Rogoż M. (red.), O tym, co Alicja odkryła... W kręgu badań nad toposem dzieciństwa i literatura dla dzieci i młodzieży, Kraków, s. 182. 
Michałowska Marianna, 2011, Senne marzenia - fotografia $w$ świecie dziecka, w: Rodziewicz E., Cackowska M. (red.), Wychowanie przez świat fikcyjny dla świata rzeczywistego, Gdańsk, s. 355-370.

Ostrowicka Beata, 2012, Jest taka historia. Opowieść o Januszu Korczaku, Richter-Magnuszewska J. (il.), Łódź.

Piątkowska Renata, 2014, Wszystkie moje mamy, Szymanowicz M. (il.), Łódź, s. 20-21.

Porębski Mieczysław, 1980, Czy metaforę można zobaczyć?, „Teksty”, nr 6 (54), s. 61-78.

Rusinek Michał, 2011, Zaklęcie na „w”, Rusinek J. (il.), Łódź.

Rusinek Michał, Olech Joanna, 2010, Kiedy byłem mały / Kiedy byłam mała, Olech J. (il.), Łódź.

\section{O Autorce:}

Katarzyna Wądolny-Tatar - dr hab., adiunkt w Katedrze Poetyki i Teorii Literatury IFP Uniwersytetu Pedagogicznego w Krakowie. Autorka rozpraw Metaforyka oniryczna w liryce Młodej Polski (2006), Kołysanka w liryce XX i XXI wieku. Emergencja gatunku literackiego (2014), współredaktorka monografii Kamień $w$ literaturze, języku i kulturze, tom I i II (2013), Nowe poetyki miejskie. Z problematyki urbanistycznej $w$ literaturze XX i XXI wieku (2015) i czasopisma „Annales Universitatis Paedagogicae Cracoviensis. Studia Poetica”. Kieruje Pracownią Literatury dla Dzieci i Młodzieży w Instytucie Filologii Polskiej UP. 